\title{
TURKISH PARTICIPATION TO 1893 CHICAGO EXPOSITION
}

\author{
GÜLSEN SEVINÇ - AYŞE FAZLIOĞLU
}

\begin{abstract}
Chicago Exposition was carricd out in 1893 , the $400^{\text {th }}$ anniversary of the discovery of America by Columbus, to prove the predominance of the country's economy and culture to the entire world. Ottoman Empire was represented in this international gathering. The participation of the Ottoman Empire was due to a special invitation to Sultan Abdulhamit II by a delegation sent by the United States. The Ottoman Empire, considered as "the Sick Man of Europe" by the whole world cstablished a commission for the exposition to clear up this reputation.

An Ottoman subject, Süleyman Bustani Efendi published a monthly newspaper in Turkish during the Chicago Exposition in United States. The 138 photographs found in the National Palaces Photography Collections present a rich visual piece of work on Ottoman participation to the Chicago Exposition, which are elaborated in this article.
\end{abstract}

\section{KEYWORDS} Relations.

World Fairs; Chicago Exposition-Turkey; the United States; Cutural 
International exhibitions, while aimed at trade and industrial objectives in the wide range of promotion and marketing of the products that were produced by the raw materials obtained from the colonies, provided interactions in culture and art among the countries in the course of time.

The exhibitions shown to the eastern and the western World that there was a different industry, economy and art other than theirs. While these extensive activities followed a racetrack in economy and industry, they were considered as a way of identifying the cultural and artistic superiority in time. 1893 Chicago Exposition, bearing an international feature, was a multiparticipated exhibition, in which the Ottoman Empire was also represented. The 138 photographs found in the National Palaces Photography Collections present a rich visual piece of work.

Chicago Exposition was carried out in 1893 , the $400^{\text {th }}$ arıniversary of the discovery of America by Columbus, to prove the predominance of the country's economy and culture to the entire world. Christopher Columbus, who inspired the idea of the exhibition, had tried to reach India thereby passing through the Atlantic Ocean. Living on the sales of his calligraphic maps, Columbus had his day when he dropped by the Larabida Monastery on a hill near the shore to take water for his son and met with Father Juan Perez, while he and his 8-10 years-old son were on the way back to home from Portugal. Patronized by the Queen of Spain Isabella with the reference of Father Juan Perez, Columbus set sail from Spain to west with 3 ships to discover India. Instead, at the end of his journey he discover America in 1493. ${ }^{1}$

The idea to stage an exposition to commemorate this important discovery, were put forward as early as 1880 s, which gained enough momentum in the public by 1888 , thus a competition occured among the regions in 1889, and finally Chicago was selected as the exposition site by a vote of 157 in the American Congress. A bill to authorize the exposition was signed into law by President H. Harrison in 1890 . According to the act, an international exposition was to be held in Chicago city of the

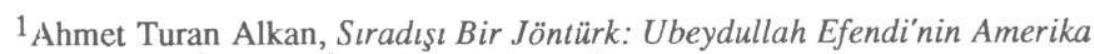
Hatıraları, İstanbul, İletişim, 1989, p. 181. 
Illinois State about the products of soil, mine and sea in the subjects matters of art and industry; the exposition was supposed to open in May and close not later than October 26, 1893. A section of the act called for a naval review in New York Harbor and invited foreign nations to send warships to join the U.S. Navy at Hampton Roads, Virginia.

The World Columbian Commission, established just after the act was signed, quickly laid the groundwork for the exposition and formally notified the President of the United States that all preliminary requirements of the congressional act had been fulfilled. He then issued a proclamation of invitation to all nations accompained by a letter from the secretaires of State and of the Treasury detailing regulations and instructions for foreign exhibitors. The exposition was promoted by the Department of Publicity and Promotion of the Exposition.

1893 Chicago exposition was held on a small strip of land known Midway Plaisance connecting Jackson Park to Washington Park near the Lake Michigan. The exposition was opened by he President of United States, Grover Cleveland, in May 1, 1893.

A replica of the Larabida Monastery, the historic starting point of Columbus' adventure was erected in the 1893 Chicago Exposition by the Lake Michigan. Here the personal belonging and works of Columbus and the others were exhibited. ${ }^{2}$

Plenty of artists and architects contributed to the 1893 Chicago Exhibition. Under the decision of the Board of Architects all the building were made at the same height using the same materials. Various building were constructed in the exposition. First of these was the Administration Building by the New York architect Richard M.Hunt. This building was the administrative center for the exposition authorities. Passing by the Administration Building, there was the Court of Honor, where the Statue of Republic and Macmonies Fountain were placed with a pool in the middle. After the Administration Building the visitors were following the way to the Machinery Building from the Court of Honor. Within the $435500 \mathrm{~m}^{2}$ grand hall of this building, lots of

${ }^{2}$ Bruce R. Schulman, Interactive Guide to the Word's Columbian Exposition, 1996-1997, at: [http://user.vnet.net/schulman/Columbian/columbian.html]. 
things like Whitney's cotton gin machine, 127 dynamos for energy supply and 43 steam machines were displayed. The Agricultural Building with its $400.000 \mathrm{~m}^{2}$ was a work of New Yorkers McKimm, Mead and White and included exhibitions of observatories, model farms, animals, machines and tobaccocs. In front of the Agricultural Building, the ship-models of Santa Maria, Vinna and Pinta of Christopher Columbus were placed. 140-room Fine Arts Building placed on the north side of the North Canal by Charles Atwood ${ }^{3}$.

During the 1893 World Columbian Exposition, prizes were offered to artists in the fields of sculpture, painting and decorative arts. Other than the works of American painters John Singer Sergeant, Thomas Eakins and Winslow Homer, some of the famous European painters like Pisaro, Cassat and Renoir were also clisplayed. The well-known Russian painter Aiazovsky, who had worked for the Ottoman palace for some time, visited the cities New York, Boston, Philadelphia, Washington as well. During this visit, Aivazovsky performed 14 works, 5 of them related with Christopher Columbus like "The Columbus' ceremonial Entrance to the Island San Salvador" or "The Rescue of Columbus". These paintings were exhibited in 1893 Chicago Exposition. ${ }^{4}$

The Manufactures Building, one of the most important buildings of the exposition was a work of George B. Post on an area of $11.000 \mathrm{~m}^{2}$. In this building, sales of the exhibited objects were also available. Typewriters Company Tiffany \& Remington, the Yerkes Telescope of the University of Chicago weighing 70 tons, and Bach's Keyboard were exhibited in this building. The Manufactures Building, where everything from garments to gramophones were on display had English, Russian, French, Japanese, Chinese, Austrian, German and American pavillions. The furniture of the Bavarian King's Palace, Mozart's Piano, a copy of the Lincoln's opening speech were also exhibited. The Ministry buildings of the American Defense, Finance, Interior, Justice, Agriculture and Communications departments were all on the

3 Julie K. Rose, World's Columbian Exposition: Idea, Experience, Aftermath, Unpublished MA Thesis, University of Virginia, Department of EnglishAmerican Studies, 1996.

${ }^{4}$ Pars Tuğlacı, Ayvazovsky Türkiye'de, İstanbul, İnkılâp ve Aka, 1983, p. 17. 
northern side of the Court of Honor. A great Californian tree, carrier pigeons, international coins exhibited there were also worth of seeing.

The Fish and Fisheries Building was by the exit of the Fine Arts Building in the Court of Honor and was a work of Henry Ives Cobb from Chicago. The Woman's Building by Sophie Hayden from Boston was operating as the administrative center for the Committee of the Women Administrators on an area of $80.000 \mathrm{~m}^{2}$. Although both the works of men and women were on exhibit, because the building was primarily designated for the women, the things that were made by and attracted the women were dominant. A copy of handwritten Jane Eyre by Bronte, various international costumes, works of Mary Cassat, and a copy of the US Act enabling the women to apply to the constitutional court were some of those being exhibited.

On the right side of the Woman's Building, the work of Jenney and Mundie, the Horticultural Building was situated on a 1 acred land. In this building, 8 green houses, as well as a Japanese Garden, a Mexican Desert, the inlet-line of the State of Ilinois, and strawberry samples, Austrian Pine Trees, Oregon pots and pans (within jams), a wine cellar from Germany, and 1600 types of orchids, and an orange tower from South California at a height of 35 foot were exhibited. The Horticultural Building was seen from the Wooded Island, where 100.000 rosebushes and 500.000 violets were planted.

Transportation Building was a work of Adler \& Sullivan. The Golden Gate made by Frank Lloyd from the Sullivan Company was very famous. The first locomotive and railways in the United States, the English warship models, a car from the Etruscan Museum in Florence, latest bicycle models, a ship model of real size were exhibited there. Taking the Court of Honor on the back, one could see the Mines and Mining Building on the East. The exhibitions of the Kimberley Diamond-Mining Company, a model of the Statue of Liberty made of salt, and a silver statue of the artist Ada Rehan were seen in the building.

On the left of the Mines and Mining Building, the most popular building of the exposition, the Electricity Building of Howe and Van Brunt from Kansas was placed on an area of 6.000 
$\mathrm{m}^{2}$. Electricity was an unusual thing for most Americans. The points of interest were the illuminated buildings, railways, phonographs, teleographs, steamy and electric sleds, and the demonstrations within the building. The music played by an orchestra in New York was tranferred via telephone to the Electricity Building, and a great loudspeaker was put in for people to listen the music. A villa in which electrical equipments were used was also on display. Others exhibited were the electric lamps, elevators, electric fans, sewing machines, robbery alarms, heaters, washing machines and irons as well as the world's first telegraph machine. Like the first sismograph, the first kinetoscope by Edison, the first film machine, and a light tower at a height of 82 foot with 82.000 bulbs were displayed in the exposition. ${ }^{5}$ As we have understood from our photography collections, there supposed to be a Forestry Building, too.

Midway, a self-contained entertainment district in the cross section of the Washington and Jackson Parks, helped in off-setting the expenses of the Chicago Exposition. In Midway there were buildings and exhibitions of different countries. 23 of the 43 contributing nations attended the exposition. 1893 Chicago Exposition was the first international exhibition, which all the nations had a chance to exhibit their own resources.

There had been many activitics in Midway, some of which we can follow from the photography collections. The Vienna cafe in the Old Vienna Village, The Blarney Castle built in the Middle Age character in the Irish village, the American-Indian Exhibition, the German Village, the first revolving wheel of the world specially made for this exposition -the Ferris Wheel, and the streets of the Cairo are those views we can reach.

In accordance with the sources we have, there were some interesting buildings and activities other than those above. For instance the Algerian Theater, the Austrian Village, the Balloon Ascension up to $1500 \mathrm{ft}$, the East India Bazaar, Eiffel Tower in miniature, French cider press for sale of cider, Electric Scenic Theater, and scenes under colored lights, light shows, the German Village and the concert garden, Hungarian Orpheum with Gypsy Band, international dress and costumes, Arabian Palace, covered-

\footnotetext{
${ }^{5}$ Rose, World's Columbian Exposition.
} 
swimming pool, Venice-Murano glassware exibit, Sliding Railway were of interest.

The entertaintment district Midway beared an educational aspect, too. In this exposition, the World Congress reached about 700.000 listeners. There were meetings about education, architecture, music, social reform, medical science, trade and science in Midway. ${ }^{6}$

\section{Ottoman Participation}

The participation of the Ottoman Empire was due to a special invitation to Sultan Abdulhamit II by a delegation sent by the United States. The Ottoman Empire, considered as "the Sick Man of Europe" by the whole world, established a commission for the exposition to clear up this reputation. The commissioner of the Ottoman Exposition was Sadrazam (the Grand Vizier) Hakkı Pasha, and his assistant Fahri Bey.

An Ottoman subject, Süleyman Bustani Efendi published a monthly newspaper in Turkish during the Chicago Exposition in United States. Writing out his exposition memories, the author of the newspaper was Mehmet Ubeydullah Efendi. The Servet- $i$ Fünun magazine No. 93, dated October 22, 1892 was the special edition for Christopher Columbus. In the cover there was a picture of Columbus, inside pictures and articles about him.

In the cover of the Servet-i Fünun magazine No. 131, dated September 14, 1893, there were the pictures of the commissioner Hakkı Pasha and his assistant Fahri Bey as well as related information inside.

Designed by Robert Levy, the representative of Sadullah Suhami and Constantinople Company the Turkish Village had great tents, a bazaar, a mosque and a theatre. The mosque had a dome at the height of $60 \mathrm{ft}$. and it is one of the earliest mosques built by a caliph on the lands where Islam is not widespreand. There was a tent offering lemonades, sorbets, some Turkish drinks with orange, banana, raisin and tamarind to the visitors by the 
mosque. In the south, the silver throne of the Sultan in a 160 years old Persian Tent, used once upon a time in war and hunting entertainments, was set up. Various types of carpets, rugs, embroideries, silver items, copper trays, jewels and valuable stones as well as handicrafts were sold in 40 sales pavillions. In the Turkish Cafes visitors were offered mocha and narghile, and in the village theater, Turkish traditions were introduced with the play "A Wedding in the East". ${ }^{7}$ In his memories Ubeydullah Efendi describes the Turkish Village as follows:

... Two things have caught my eyes in the Turkish Village. One of those was a panorama seen by the public including an interior appearance of St. Sophia, a street in Şehzadebaşı, the bridge in Tophane Street, the shore of the Dolmabahçe Palace and some more views. Apart from these there were also some pictures about the ElAqsa Mosque in Jerusalem, and parts of Syria. In short all were 18 pieces. The second one was the cotton candy... ${ }^{8}$

The Ottoman Exposition Building was across the Fisheries Building. This building was a copy of the Ahmet III Fountain, originally built in between 1728-29 by Sultan Ahmet III in front of the Topkap1 Palace. In this educational section of the exposition products manufactured in Turkey were exhibited. In this building there were glass cases displaying silver and gold jewelleries, clogs, torpedo boats, soaps, odors, metals and coffee juxtaposed. Back side of the building the offices, a coffee room and a reception room were located. ${ }^{9}$

There are 8 pictures in the National Palaces Collection showing the Ottoman Exposition and the official court. In one of the interior pictures of the Ottoman Exposition Building, the glass cases and the products manufactured in Turkey are visible. In another, the Ottoman court carpets, draperies, furniture and books as well as a painting on the floor attract attention, which most probably belonged to Osman Hamdi Bey. Further, the Servet $i$ Fünun magazine No. 212, dated April 4, 1895 cited from the American Century Magazine that one of the works of Osman

${ }^{7}$ World Columbian Exposition of 1893, Paul V. Galvin Library Digital History Collection, Illinois Institute of Technology, at: [http://columbus.gl.iit.edu/front1.html], p. 17.

${ }^{8}$ Alkan, Ubeydullah Efendi'nin Amerika Hatıralarl, p. 191.

${ }^{9}$ World Columbian Exposition of 1893, p. 908. 
Hamdi Bey in the 1893 Chicago Exposition was bought by the Philadelphia Municipality to be exhibited in the Philadelphia Museum.

Among the various documents analyzed in the Naval Museum Archives, we have also gathered some information about the objects sent to 1893 Chicago exposition. It is learnt that Ereğli coal and samples of other mines as well as some items from the Great Dockyard (Tersane-i Amire) which was established in 1453 by the Sultan Mehmet II (Fatih) had been sent to the Chicago Exposition.

Thanks to those documents of the Naval Museum (Naval Museum, D.B. No.: $851 \mathrm{~A} / \mathrm{E}$ ), we obtain some more information about the objects rewarded in the Chicago Exposition: The torpedo boat with its $26 \mathrm{mph}$ speed manufactured in the Great Dockyard, the carved bookcase made of ebony, highly qualified rowboat, electric rudder and the control button and the boat, the Naval Ministry due to the scientific publications of the Great Dockyard about sea and mathematics were all prized by the World Columbian Comission. It is also known that Sultan Abdülhamid II, a very good carpenter at the same time, had a first rank in the Exposition. ${ }^{10}$ One of the earliest industrial organizations of İstanbul, the Feshane had two rewards for its wool-textiles and fezzes. The inscription on the reward about the wool-textiles was as follows: ${ }^{11}$

Textiles colored green and red. Soft, tight and thin, result is perfect quality. The factory that is a state institution manufacturing the best products of its country is awarded thanks to their exhibition of all products.

The inscription about the red and green fezzes was as follows:

Dark red fezzes: A collection of a very ornate and good workmanship. Award is because of the light red handwoven fezzes which are water dependable, firm- colored, soft and elastic made of good quality and embroidery.

10ìskender Pala, "Sözün Sultanları", Antik Dekor, Vol. 50, 1999, p. 86.

${ }^{11}$ Önder Küçükerman, Türk Giyim Sanayinin Tarihi Kaynaklarl, İstanbul, GDS Yayınları, 1996, p. 245. 
Both the Dockyard and the Feshane were institutions under state control. The state control on the Ottoman economy was shaken by the 1838 Ottoman-English Trade Agreement. As a result of this agreement cheap and high-quality European products entered the Ottoman Market. On the other hand, the increasing demand for raw material of the devoloping European industry established a market for the very rich Ottoman resources. Not only the European market, but also the Ottomans had the opportunity to go into the American market with the 1893 Chicago Exposition. 